\title{
Transferrin Receptor-Targeted Anti-RRM2 siRNA CALAA-01
}

National Cancer Institute

\section{Source}

National Cancer Institute. Transferrin Receptor-Targeted Anti-RRM2 SIRNA CALAA-01. NCI Thesaurus. Code C78450.

A proprietary transferrin receptor-targeted nanoparticle preparation of a non-chemically modified small-interfering RNA (siRNA) directed against the M2 subunit of ribonucleotide reductase (RRM2) with potential antineoplastic activity. Upon administration, transferrin receptor-targeted anti-RRM2 siRNA CALAA-01 binds to transferrin receptors (TfRs), releasing anti-RRM2 siRNA after endocytosis; anti-RRM2 siRNA silences the expression of RRM2 via the RNAi pathway, impeding the assembly of the holoenzyme ribonucleotide reductase (RR) which catalyzes the production of deoxyribonucleotides. As a result, inhibition of cellular proliferation may occur in cells expressing $\mathrm{TfR}$, a cell surface protein overexpressed on various cancer cell types. 